\title{
Fertility and maternal hours of work in Ethiopia: a case study in the Amhara region
}

\author{
Chalachew Getahun Desta ${ }^{1}$ \\ Department of Geography and Environmental Studies, \\ Bahir Dar University, Bahir Dar, Ethiopia
}

\begin{abstract}
Theoretical evidence relating to children's economic effect suggests that mothers work fewer hours with a large number of young children and more hours when children are adults. The majority of empirical studies find results consistent with this expectation, but there are some studies which fail to confirm this theoretical prediction for developing countries. Using data from a household sample survey of rural and urban married women with at least two live children, this study employs the Two-Stage Least Squares model to document the maternal hours of work effected by the number of children. We find that children have positive effects both for the rural and urban mothers' hours of work when all households are considered, but not for urban mothers when households are categorized by the age groups of their children. Generally, our results contradict traditional theory and show that Ethiopian mothers with large numbers of young children work longer.
\end{abstract}

Key words: Endogeneity, lifecycle, observed fertility, predicted fertility, hours of work.

\section{Résumé}

L'évidence théorique rattachant l'effet économique d'enfants suggère que les mères travaillent moins d'heures avec le grand nombre de petits enfants et de plus d'heures où les enfants sont des adultes. La majorité d'études empiriques trouve des résultats en accord avec cette attente, mais il y a quelques études qui manquent de confirmer cette prédiction théorique pour les pays en développement. En utilisant des données d'une enquête de promotion du ménage de femmes mariées rurales et urbaines avec au moins deux enfants vivants, cette étude emploie le Deux stade la Moindre partie de modèle de Carrés pour documenter les heures maternelles d'effet de travail du nombre d'enfants. Nous constatons que les enfants ont des effets positifs pour les heures des mères tant rurales qu'urbaines de travail quand toutes les maisons sont considérées, mais pas ainsi pour les mères urbaines quand les maisons sont classées par catégories par les tranches d'âge de leurs enfants. Généralement, nos résultats contredisent la théorie traditionnelle et montrent que les mères éthiopiennes avec les grands nombres de travail de petits enfants plus long.

Mots clés: Endogénéité, cycle de vie, fécondité observée, fécondité prévue, heures de travail.

\section{Introduction}

The Ethiopian national population policy was launched in 1993 with the overall aim of ensuring a balanced population and economic growth (TGE, 1993). Despite its promulgation, policy implementation had been weak partly due to insufficient political commitment and weak implementation capacity until 2005, when both fertility rates and population were given increasing attention, as is evident in Ethiopia's consecutive national development policy and programs (MoFED, 2002, 2006, 20I0; UNDP, 200I; UN Population Division, 2005; IMF, 2006; MWUD,
2007). The national development plans identify, among other things, ensuring maternal labor market participation as critical for achieving the planned development. One major strategy to achieve this, as suggested by the plan documents, is ensuring balanced population and economic growth, for example through reducing fertility.

In Ethiopia, fertility has been one of the highest among developing countries, but there seems to be a substantial decline in recent years. Modern contraceptive use has recently risen, for example, from II\% in 2000 (Central Statistical Authority of Ethiopia - CSA hereafter,

I. Correspondence e-mail: chalget@gmail.com or chalzert@ymail.com, Tel: +25I-9I3-103378, P. O. Box: I476 Bahir Dar, Ethiopia 
2000: 50) and $15 \%$ in 2005 (CSA, 2005) to $29 \%$ in 2010 (CSA, 20II: 10). Correspondingly, total fertility rate is declining substantially though still high, for example, from 5.9 in 2000 (CSA, 2000: 37 ) and 5.4 in 2005 (CSA, 2005) to 4.8 in 2010 (CSA, 20I I: 8). The average annual rate of population growth has also dropped from $2.9 \%$ during the 1984-1994 intercensal period to 2.6\% during the 1994-2007 intercensal period (UNFPA, 2010; Hailemariam, Alayu, and Teller, 20II: 303).

However, with fertility declining much more slowly than mortality, the country is still in the early stage of the demographic transition (Ringheim, Teller and Sines, 2009: I; Gebreselassie, 2011: 19). Although the urban population is growing at a rate of $3.5 \%$, which is significantly higher than the rate of total population growth (UNFPA, 20I0: 10I), 83\% of the population still reside in rural areas. The mode of farming is primitive and labor intensive and, as a result, child labor is high and remains critically important in agriculturally heavily traditional economies like Ethiopia's (Aassve et al., 2005). Focusing more narrowly on issues pertinent to the present study, the percentage of women working in productive activities is low (TGE, 1993). For example, the Ethiopian DHS 2005 (CSA, 2005) shows the female participation rate to be $32 \%$ at the time of the survey. This low maternal participation might have an important implication for the planned growth and transformation, as theory predicts that increased maternal hours of participation in productive work increases household wellbeing, thereby decreasing fertility despite the mixed empirical evidence which shows that net wellbeing depends on the balance between the loss of a mother's childcare time and the increased consumption expenditure from rising household incomes (Baum, 2003; Morrill, 2008; Chatterji, Markowitz and Brooks-Gunn, 20II), in addition to changing childcare patterns (Bianchi, 2000).

These being the facts regarding fertility and economic variables in Ethiopia, the question of interest to the present study, however, is whether, and the extent to which, fertility influences the economic wellbeing of Ethiopian households. In Ethiopia the effect of the demographic trend described above is not as clear. Theoretically, it is expected that since young children require more childcare at home than adult children, mothers work fewer hours, if any, with an increasing number of young children and work more when children are adults. The vast majority of empirical studies find results consistent with this theoretical prediction, but there are some studies in developing countries which fail to replicate this relationship (see e.g. Aghajanian, 1979 for Iran; Angrist and Evans, 1998 for similar evidence for other countries; Cho, 2006 for Korea; Solomon and Kimmel, 2009 for Ethiopia).

The remaining part of this paper is organized as follows: section 3 discusses the variables, the data and the empirical model, section 4 describes some background characteristics of the study population, section 5 presents the analysis, section 6 presents discussion of the results and section 7 concludes.

\section{Data, the variables and the empirical model}

\section{The data}

Data were collected from a sample of 254 rural and urban households whose members participated in productive work four months prior to the commencement of the survey. The urban households were selected from four kebeles $I$ out of the total of nine kebeles of the Bahir Dar City, the Amhara Regional State capital (see Appendix I for location map). Sampling was first stratified by physical qualities of housing units ${ }^{2}$. We selected two kebeles with informal, substandard housing conditions and two other kebeles with formal, standard housing conditions. Then sample households were selected randomly from each kebele. The rural sample households were selected from two rural districts located near the city. Households were randomly selected from one kebele each from the two districts. As rural households relative to urban households are socio-economically less diverse, we did not feel the need to further stratify the rural samples.

In the interview, married mothers with at least two children living in the household were asked to provide a wide range of demographic and socio-economic data. The number of questionnaires presented was equal for both the rural and urban households. A total of 258 (out of 280 ) questionnaires were completed (I 31 for urban and 127 for rural). However, 4 of the 131 
urban households with relatively higher missing values were discarded so that both the urban and the rural sample sizes are equal. The reason for this is also the need to allow easy comparison of the results between the urban and the rural samples. This makes the total valid sample size 254.

Where results from the quantitative data alone have been inconsistent with the theoretical expectation or with most previous evidence, there was qualitative observation and interviews with survey households. Overall, sixteen rural households were selected for observation and qualitative interview (eight from each rural kebele). There were no a priori listed set of specific questions for the qualitative interview, but the interview goals and subject topic were presented and the respondent was guided to focus on the relevant issues (see e.g. Skop, 2006: 8 for a similar procedure in the context of focus group discussion). This was followed by a general question on the household's demographic and socio-economic characteristics, and new specific questions emerged from the responses as the interview went on with the households. An observation was, in addition, made where a member or members of a household has/have been engaged in any type of work activity for the household.

In addition, government policy and programs document analysis was used as data source. Specifically, the national population policy document of Ethiopia and other policy and program documents related to population and development such as the Sustainable Development and Poverty Reduction Program (SDPRP), Plan of Action for Sustained Development to End Poverty (PASDEP), Growth and Transformation Plan (GTP) and other relevant sectoral policies and programs were reviewed.

Data were analyzed first using the full sample and then separately for the urban and the rural sub-samples, splitting the full sample into its urban and rural components. The reason for the separate analysis was the need to see if the widely acknowledged rural-urban difference in fertility also holds for the economic wellbeing effect of the number of children.

\section{The variables}

The objective of the present study is to investigate the effect of the number of children on the mother's time allocation in productive work participation. The dependent variable is the mean duration in hours spent on productive work per day and the independent variable of interest is the number of children. In addition, a number of other demographic and socio-economic variables were also used as control variables. The variables controlled include average age of children, sex and age of the household head, female spouse's age at first marriage, education level of the female spouse, contraceptive use (yes $=I$; otherwise, 0 ), loan receipt (yes $=I$; otherwise, 0 ) and existence of members in the household other than parents engaged in productive or non-productive work. These variables were selected because they are used in almost all previous studies on a similar topic.

There were also other variables included such as the education level of the male spouse, household income, household assets, consumption expenditure, farmland size and housing characteristics also widely used in previous research. However, the first four variables were detected to have multicolinearity with other variables in the model and were thus dropped from analysis. Farmland size and housing characteristics were not included because urban households do not have data on farmland size and housing characteristics does not make any difference among rural households.

Defining maternal hours of productive work: The Millennium Development Goals (MDGs) set out eight goals and several targets to address women's problem of low labor force participation. The third goal of the MDGs is to promote gender equality and empower women as a means to reduce poverty and increase wellbeing of the household. This requires, as clearly stated in indicator 3.2 of the MDG 3, increasing the proportion of women participating in the paid labor market, the preferred wellbeing indicator.

In line with this, most, if not all, previous research defined productive work as that component of work which is paid or from which the woman directly earns income. However, this is problematic for a study based on a rather smaller household survey in a poor economy as is the present study, where, due to the sample size, the proportion of women participating in the paid labor market is low. Therefore, in the present study productive work is defined very 
broadly to include paid or unpaid; employed or self-employed; formal or informal; or primary, secondary or tertiary. However, it does not include childcare and domestic chores such as cooking, cleaning/washing, fetching water, fire wood collection and related activities, except where these activities are directly related to income earning.

The adoption of the rather broader definition of productive work in the present study may not precisely indicate wellbeing, but we hope that it gives an insight since the paid labor is also one component in the broader definition.

\section{The empirical model}

The causal effect of fertility in the economic wellbeing effect of children is complicated by the endogeneity of fertility. Although there are a few studies which failed to find endogeneity (see e.g. Orbeta, 2005), the fact that fertility is endogenous to maternal work participation and hours of work is widely acknowledged in the literature, in the presence of which the use of the ordinary least squares estimator biases the effect of the number of children.

While the econometric literature offers various approaches to account for endogeneity, one of these is the use of an instrumental variable. Using instrumental variable methods yields unbiased estimates even when fertility is or is not exogenous (Schultz, 2007). Different studies used different instrumental variables to generate exogenous variation in fertility. These include, for example, twin first birth (Chun and Oh, 2002; Kim et al., 2009), abortion legislation (Bloom et al., 2007), contraceptive choice of couples (Kim and Aassve, 2006), sibling sex composition (Angrist and Evans, 1998; Cruces and Galiani, 2005), sibling sex composition and contraception unavailability (Aassve and Arpino, 2007) and sex of the first birth (Chun and Oh, 2002; Orbeta, 2005).

Following Angrist and Evans (1998), the present study uses Two Stage Least Squares (2SLS) instrumental variable procedure ${ }^{\square}$, which is the most common instrumental variable estimator (Wooldridge, 2009). The instrumental variable used consists of sex composition of the first born two siblings (same sex $=1$; otherwise, $0)$. The choice of this instrument is dictated by the fact that sex composition of children is a random assignment and hence the sex of the siblings has no direct significant effect on maternal hours of work participation while it impacts the number of children.

In specifying the model, we begin with the structural form, $Y_{\mid \mathrm{i}}$, which can be given as:

$$
Y_{1 i}=\alpha_{0}+\chi_{1 i} \alpha_{1}+Y_{2 i} \beta+U_{i}
$$

where $Y_{1 i}$ is the mean duration in maternal work hours for the $\mathrm{i}^{\text {th }}$ household

$\alpha_{1}$ is parameter coefficient of the vector of an exogenous variable, ${ }^{x_{1 i}}$

$\beta$ is parameter coefficient of the vector of the number of children, $Y_{2 i}$

$U_{i}$ is an error term assumed to be normally distributed with mean zero.

However, the literature tells us that the number of children $\left(Y_{2 i}\right)$ is endogenous. I.e.,

$\operatorname{Cov}\left(Y_{2 i}, U_{i}\right) \neq 0$

If the equation is estimated by OLS, the estimate will be biased. Therefore, $Y_{2 i}$ should be itself predicted first in a reduced form as a function of sibling sex composition, $Z_{i}$.

$\hat{Y}_{2 i}=\delta_{0}+\chi_{2 i} \delta_{2}+Z_{i} y+e_{i}$

where, $\hat{Y}_{2 i}$ is the number of children to be estimated for the $\mathrm{i}^{\text {th }}$ household

$\delta_{2}$ is estimated parameter of the vector of exogenous variables, ${ }^{x}{ }_{2 i}$

$\gamma$ is estimated parameter of the vector of the instrumental variable, ${ }^{Z}$

$e_{i} i$ is an error term associated to household $i$.

The instrumental variable, $Z_{i}$, is assumed to be uncorrelated with the error term, but partially correlated with the number of children. I.e.,

$\operatorname{Cov}\left(Z_{i}, U_{i}\right)=0$

and,

$\operatorname{Cov}\left(Z_{i}, Y_{2 i}\right) \neq 0$

The instrument is also assumed to be uncorrelated with other exogenous covariates. I.e,

$\operatorname{Cov}\left(Z_{i}, X_{1 i}\right)=0$ 
Because $U$ is unobservable, $\operatorname{Cov}\left(Z_{\mathrm{i}}, U_{\mathrm{i}}\right)$ is untestable, unlike $\operatorname{Cov}\left(Z_{\mathrm{i}}, Y_{2 \mathrm{i}}\right)$ which can be readily tested using the data.

Once the number of children is exogenously predicted in (3), the final equation which estimates the mother's hours of work can be specified by inserting the predicted number of children, $Y_{2 i}$, in place of $Y_{2 i}$ as:

$$
Y_{3 i}=\alpha_{0}+x_{3 i} \alpha_{3}+\hat{Y}_{2 i} \beta+\varepsilon_{i}
$$

where, $Y_{3 i}$ is the mean duration in maternal work hours for the $\mathrm{i}^{\text {th }}$ household

$\alpha_{3}$ is parameter coefficient of the vector of exogenous variables, ${ }^{x}{ }_{3 i}$

$\beta$ is parameter coefficient of the estimated number of children, $Y_{2 i}$

$\varepsilon_{i} i$ is an error term associated to household $i$.

The estimated maternal hours of productive work participation, ${ }^{Y_{3 i}}$, is now assumed to be unbiased.

\section{Characteristics of the study popula- tion}

The tables below offer some descriptive statistics on the demographic and economic characteristics of sample households. Table I and Table 2 provide mean values and frequency respectively for sample households on selected demographic and economic variables across the rural-urban economies. Not surprisingly, Table I shows that households in the urban sub-sample have higher average age at first marriage/child bearing, educational level, and asset value compared to households in the rural sub-sample. Table I also shows that while having older and smaller numbers of children, urban mothers work for relatively fewer hours compared to their rural counter parts. The older age and smaller number of urban children is probably due to the relatively higher educational attainment of urban women leading to the higher rates of contraceptive use (Table 2) and the delayed age in first marriage/child bearing (Table I).

Table I Demographic and economic characteristics of sample households (means)

\begin{tabular}{|c|c|c|c|}
\hline \multirow[t]{2}{*}{ Variables } & \multicolumn{3}{|l|}{ Mean values } \\
\hline & Full sample & $\begin{array}{l}\text { Urban sub- } \\
\text { sample }\end{array}$ & $\begin{array}{l}\text { Rural sub- } \\
\text { sample }\end{array}$ \\
\hline Age of household head & $\begin{array}{l}44.9843 \\
(11.0890 I)\end{array}$ & $\begin{array}{l}48.4724 \\
(11.54225)\end{array}$ & $\begin{array}{l}41.496 I \\
(9.44228)\end{array}$ \\
\hline Number of children & $\begin{array}{l}4.8701 \\
(2.3089)\end{array}$ & $\begin{array}{l}4.4252 \\
(2.1139)\end{array}$ & $\begin{array}{l}5.3150 \\
(2.4159)\end{array}$ \\
\hline Average age of children & $\begin{array}{l}13.2800 \\
(7.83000)\end{array}$ & $\begin{array}{l}16.1015 \\
(8.83351)\end{array}$ & $\begin{array}{l}10.4584 \\
(5.38747)\end{array}$ \\
\hline Age at first marriage & $\begin{array}{l}15.7618 \\
(3.61805)\end{array}$ & $\begin{array}{l}16.9961 \\
(3.85990)\end{array}$ & $\begin{array}{l}\mid 4.5276 \\
(2.88352)\end{array}$ \\
\hline Age at bearing first child & $\begin{array}{l}18.6142 \\
(3.43902)\end{array}$ & $\begin{array}{l}19.8031 \\
(3.81526)\end{array}$ & $\begin{array}{l}17.4252 \\
(2.51825)\end{array}$ \\
\hline Education level of female spouse & $\begin{array}{l}3.4705 \\
(4.40245)\end{array}$ & $\begin{array}{l}5.8031 \\
(4.82395)\end{array}$ & $\begin{array}{l}1.1378 \\
(2.16270)\end{array}$ \\
\hline Value of household assets & $\begin{array}{l}\mid 2780.5993 \\
(16320.643 \mid 2)\end{array}$ & $\begin{array}{l}14623.3780 \\
(16900.0030)\end{array}$ & $\begin{array}{l}10937.8205 \\
(15568.722 \mid\end{array}$ \\
\hline $\begin{array}{l}\text { Mean duration in hours per day of maternal } \\
\text { productive work participation }\end{array}$ & $\begin{array}{l}3.5308 \\
(4.11990)\end{array}$ & $\begin{array}{l}2.4719 \\
(3.43765)\end{array}$ & $\begin{array}{l}4.5981 \\
(4.47442)\end{array}$ \\
\hline $\mathbf{N}$ & 254 & 127 & 127 \\
\hline
\end{tabular}

Note: Standard deviations are reported in parenthesis. Source: Survey data (2010). 
On the other hand, Table 2 shows that, compared to the rural households, urban households have a higher proportion of femaleheaded households, lower proportion of households who received loans, lower rate of female spouse participation in productive work, lower proportion of households with more than two children, and a higher proportion of households with members other than parents who participate in work for the household. While the higher proportion of female-headed households and the lower rate of female productive work participation for urban relative to rural house- holds is consistent with previous evidence, the lower rate of loan receipt by urban compared to rural households is surprising, since urban households are expected to have better access to the service given their proximity to credit facilities and the relatively capital-intensive nature of urban jobs. The larger proportion of urban children working compared to the rural children is also surprising given the traditional, manual labor-intensive nature of the rural economy and also given the large amount of literature on rural child labor.

Table 2 Demographic and economic characteristics of sample households (frequency)

\begin{tabular}{|c|c|c|c|}
\hline \multirow[t]{2}{*}{ Variables } & \multicolumn{3}{|c|}{ Percentage the event occurred } \\
\hline & Full sample & Urban sub-sample & Rural sub-sample \\
\hline Household head is female & 18.5 & 27.6 & 9.4 \\
\hline $\begin{array}{l}\text { Female spouse used } \\
\text { contraceptives }\end{array}$ & 51.2 & 74.8 & 27.6 \\
\hline Household received loan & 43.3 & 35.4 & 51.2 \\
\hline $\begin{array}{l}\text { Members other than parents } \\
\text { participate in productive work }\end{array}$ & 58.3 & 63.0 & 53.5 \\
\hline $\begin{array}{l}\text { Members other than parents } \\
\text { participate in non-productive }\end{array}$ & 64.8 & 67.5 & 62.2 \\
\hline Same sex first born two siblings & 62.6 & 56.7 & 68.5 \\
\hline $\begin{array}{l}\text { Percentage of households with } \\
\text { more than two children }\end{array}$ & 83.1 & 78.7 & 87.4 \\
\hline $\mathbf{N}$ & 254 & 127 & 127 \\
\hline
\end{tabular}

Source: Survey data (2010).

\section{Results: Number of children and maternal hours of work}

Having described the characteristics of the study population, we now turn to analyzing the effect of the number of children on the maternal hours of productive work, using the Two Stage Least Squares regression model specified earlier in section 3.3. Before that, however, we describe the mean maternal hours of work participation (Table 3).

Table 3 depicts the number of children and the mean duration in hours of the mother's productive work during the specified period differ for the urban and the rural sub-samples. It shows that the mean duration generally roughly increases with an increase in the number of children for the rural sub-sample and for the full sample, but the situation is less consistent for the urban sub-sample. The table also shows that the mean duration in the hours of the mother's work participation is relatively smaller for the urban sub-sample compared to the rural subsample.

Tables 4 and 5 present results of the instrumental variable regressions. Table 4 shows the amount of variance explained for the mean duration in maternal hours of work by the number of children and control covariates. The lower $R^{2}$ is probably due to other variables omitted from the analysis (refer to section 3.2 for the list of these variables and the reasons for their omission). Note, however, that as expected the $R^{2}$ is larger for the OLS than for the 2SLS estimates for both sub-samples and the full sample. Despite the lower $R^{2}$ for the urban sub-sample compared to the rural sub-sample, it is statistically significant for both sub-samples, 
suggesting that the models are well fitted to the variables.

Table 3 Mean duration in maternal hours of productive work participation per day

\begin{tabular}{|c|c|c|c|c|c|c|}
\hline \multirow[t]{2}{*}{ No. of children } & \multicolumn{2}{|c|}{ Full sample } & \multicolumn{2}{|c|}{ Urban } & \multicolumn{2}{|c|}{ Rural } \\
\hline & $\mathbf{N}$ & Hours/day & $\mathbf{N}$ & Hours/day & $\mathbf{N}$ & Hours/day \\
\hline 2 & 43 & $\begin{array}{l}2.4318 \\
(3.63425)\end{array}$ & 27 & $\begin{array}{l}2.0881 \\
(3.53266)\end{array}$ & 16 & $\begin{array}{l}3.0118 \\
(3.84436)\end{array}$ \\
\hline $3-4$ & 76 & $\begin{array}{l}3.6685 \\
(4.02902)\end{array}$ & 44 & $\begin{array}{l}4.2175 \\
(4.01025)\end{array}$ & 32 & $\begin{array}{l}2.9137 \\
(3.99376)\end{array}$ \\
\hline $5-6$ & 76 & $\begin{array}{l}3.6661 \\
(4.51301)\end{array}$ & 32 & $\begin{array}{l}I .7151 \\
(3.35964)\end{array}$ & 44 & $\begin{array}{l}5.0850 \\
(4.7428 I)\end{array}$ \\
\hline $7-8$ & 38 & $\begin{array}{l}4.9338 \\
(3.95939)\end{array}$ & 16 & $\begin{array}{l}2.6609 \\
(3.70693)\end{array}$ & 22 & $\begin{array}{l}6.5868 \\
(3.31773)\end{array}$ \\
\hline $9-10$ & 14 & $\begin{array}{l}3.3518 \\
(4.1 \mid 367)\end{array}$ & 7 & $\begin{array}{l}.9429 \\
(1.63591)\end{array}$ & 7 & $\begin{array}{l}5.7607 \\
(4.5220 I)\end{array}$ \\
\hline$>=11$ & 4 & $\begin{array}{l}10.7532 \\
(3.74136)\end{array}$ & --- & --- & 4 & $\begin{array}{l}10.7532 \\
(3.74136)\end{array}$ \\
\hline Total & 251 & $\begin{array}{l}3.7427 \\
(4.22808)\end{array}$ & 126 & $\begin{array}{l}2.746 I \\
(3.7437 I)\end{array}$ & 125 & $\begin{array}{l}4.7473 \\
(4.45944)\end{array}$ \\
\hline
\end{tabular}

Note: Standard deviation is reported in parenthesis. Source: Survey data (2010).

Table 4 Amount of variance explained for mean duration in maternal hours of productive work by the number of children and other covariates

\begin{tabular}{|c|c|c|c|c|c|c|}
\hline \multirow[t]{2}{*}{ Model } & \multicolumn{2}{|c|}{ Full sample } & \multicolumn{2}{|c|}{ Urban sub-sample } & \multicolumn{2}{|c|}{ Rural sub-sample } \\
\hline & $\mathbf{R}^{2}$ & $\begin{array}{l}\text { Wald } \mathrm{chi}^{2} \text { (F for } \\
\text { OLS) }\end{array}$ & $\mathbf{R}^{2}$ & $\begin{array}{l}\text { Wald } \text { chi }^{2} \text { (F for } \\
\text { OLS) }\end{array}$ & $\mathbf{R}^{2}$ & $\begin{array}{l}\text { Wald chi }{ }^{2} \text { (F for } \\
\text { OLS) }\end{array}$ \\
\hline OLS & .1497 & $\begin{array}{l}4.28 \\
(.000)\end{array}$ & .1890 & $\begin{array}{l}2.70 \\
(.005)\end{array}$ & .2021 & $\begin{array}{l}2.94 \\
(.003)\end{array}$ \\
\hline 2SLS & .1477 & $\begin{array}{l}36.26 \\
(.000)\end{array}$ & .0799 & $\begin{array}{l}24.01 \\
(.008)\end{array}$ & .1746 & $\begin{array}{l}17.16 \\
(.070)\end{array}$ \\
\hline $\mathbf{N}$ & & 254 & & 127 & & 127 \\
\hline
\end{tabular}

Note: p-values are reported in parenthesis. Source: Survey data (2010).

Table 5 shows parameter estimates for the mean duration in hours worked for both models. ${ }^{4}$ It is worth noting, at this juncture, that this study does not intend to discuss coefficients from control variables (see Table 6 in Appendix I for coefficients of control covariates).

The table consists of three panels. Each panel compares results for the rural and urban locations. The first panel shows results for all households that differ only in their rural-urban location. The second and third panels show, in addition, results for households that differ by the age group of their children.

For the first panel, the table shows interesting results. First, the $2 \mathrm{SLS}$ estimate has all positive coefficients for both the rural and urban locations (the OLS estimate has negative coeffi- cient for the urban sub-sample) suggesting that an increase in the number of children is associated with an increase in the maternal hours of productive work for the households. Second, none of the coefficients is statistically significant for the 2SLS estimates, whereas for the OLS estimates coefficients are statistically significant for the rural sub-sample and the full sample, but not for the urban sub-sample.

While the lack of statistical significance for the coefficients estimated using the 2SLS model in the first panel is consistent with most previous evidence, the lack of difference in coefficient signs by rural-urban locations is surprising because the difference in the employment structure between the rural and the urban economies is expected to respond to the effect 
of the number of children differently for the rural and the urban locations.

However, the analysis above gives no allowance for the possibilities that the effect varies by the lifecycle of the households. ${ }^{5}$ This possibility is documented theoretically in the age dependency hypothesis (at population level) and empirically in cross-national, macro studies. The household level lifecycle hypothesis is empirically not well documented (see e.g. Chernichovsky, 1978; Davies, 1988; Browning and Crossley, 200 I; Kelley and Schmidt, 200 I; Dea- ton, 2005; Jappelli, 2005). Lifecycle effects are well studied using panel data which offer a unique opportunity for the possibility of tracking the changes in the effect for a given household over a period of time, which is not possible for cross-sectional data, a type used in the present study. With this limitation, however, we attempt to see if the effect of the number of children varies by the lifecycle of the households assuming that categorizing the mothers by their children's average age groups allows us to capture lifecycle variations.

Table 5 Parameter estimates for maternal hours of productive work by the number of children (with control variables)

\begin{tabular}{|c|c|c|c|c|c|c|c|}
\hline \multirow{2}{*}{$\begin{array}{l}\text { Household } \\
\text { group }\end{array}$} & \multirow[t]{2}{*}{ Model } & \multicolumn{2}{|c|}{ Full sample } & \multicolumn{2}{|c|}{ Urban sub-sample } & \multicolumn{2}{|c|}{ Rural sub-sample } \\
\hline & & Coef. & $\begin{array}{l}p>z(p>t \\
\text { for OLS }\end{array}$ & Coef. & $\begin{array}{l}p>z \\
(p>t \text { for } \\
\text { OLS }\end{array}$ & Coef. & $\begin{array}{l}p>z \\
(p>t \text { for } \\
\text { OLS }\end{array}$ \\
\hline \multirow[t]{3}{*}{ All households } & OLS & $\begin{array}{l}.3462 \\
(.1191)\end{array}$ & 0.004 & $\begin{array}{l}-.2903 \\
(.1907)\end{array}$ & 0.131 & $\begin{array}{l}.6071 \\
(.1668)\end{array}$ & 0.000 \\
\hline & 2SLS & $\begin{array}{l}.4341 \\
(.6365)\end{array}$ & 0.495 & $\begin{array}{l}.4630 \\
(1.1867)\end{array}$ & 0.696 & $\begin{array}{l}.2732 \\
(1.0295)\end{array}$ & 0.791 \\
\hline & $\mathbf{N}$ & 254 & & 127 & & 127 & \\
\hline \multirow{3}{*}{$\begin{array}{l}\text { Households } \\
\text { with children of } \\
\text { ages }<10 \text { years }\end{array}$} & OLS & $\begin{array}{l}.7139 \\
(.1670)\end{array}$ & 0.000 & $\begin{array}{l}-.0922 \\
(.5428)\end{array}$ & 0.866 & $\begin{array}{l}.8330 \\
(.2009)\end{array}$ & 0.000 \\
\hline & 2SLS & $\begin{array}{l}.6057 \\
(1.2929)\end{array}$ & 0.639 & $\begin{array}{l}-.1089 \\
(3.5429)\end{array}$ & 0.975 & $\begin{array}{l}.0331 \\
(1.5848)\end{array}$ & 0.983 \\
\hline & $\mathbf{N}$ & 100 & & 37 & & 63 & \\
\hline \multirow{3}{*}{$\begin{array}{l}\text { Households } \\
\text { with children of } \\
\text { ages }>=10 \\
\text { years }\end{array}$} & OLS & $\begin{array}{l}-.0242 \\
(.1748)\end{array}$ & 0.890 & $\begin{array}{l}-.3386 \\
(.2113)\end{array}$ & 0.113 & $\begin{array}{l}.2922 \\
(.3287)\end{array}$ & 0.378 \\
\hline & 2SLS & $\begin{array}{l}.1781 \\
(.9365)\end{array}$ & 0.849 & $\begin{array}{l}.6400 \\
(1.0213)\end{array}$ & 0.531 & $\begin{array}{l}-1.4390 \\
(23.0922)\end{array}$ & 0.950 \\
\hline & $\mathbf{N}$ & 154 & & 90 & & & \\
\hline
\end{tabular}

Note: Standard errors are reported in parenthesis. Source: Survey data (2010).

The last two panels of Table 5 show results that differ for the rural and urban locations when the effect of the age of children is considered. The second panel of the table shows results for mothers with children of ages less than ten years. The third panel shows results for mothers with children of ages ten years or older. For the urban sub-sample, the coefficient is negative for the second panel (also negative for the OLS model), suggesting, as expected, that large number of young children decreases the mother's hours of work, although it is not statistically significant. In the third panel, the coefficient is positive (negative for the OLS model), suggesting that for mothers with more adult children, the negative effect of the number of children disappears and contributes positively despite the lack of statistical significance of the coefficient.

By contrast, for the rural sub-sample, the coefficient is positive for the second panel (also positive for the OLS model), suggesting that a large number of young children increases the mother's hours of work. This result is inconsistent with traditional theory despite the statistically insignificant coefficient. However, this is not the case for the third panel where the coefficient is negative (coefficient is still positive for 
the OLS estimate), suggesting a reversal in the positive effect of the number of children. Once again, the coefficient is not statistically significant.

\section{Discussion of the results}

From the results above, two points are worthy of explanation. The first concerns the relative importance of coefficients' magnitudes for estimates from OLS and 2SLS models. That is, in some cases coefficients from exogenous estimates are larger than those from endogenous estimates, and in some other cases the reverse is true. According to Aassve and Arpino (2007), a difference in exogenous and endogenous coefficients is expected since they estimate different things owing to their reference to different samples. In terms of their relative size, most previous evidence shows that coefficients from exogenous models are larger, exaggerating the effect compared to those from endogenous models (see e.g. Angrist and Evans, 1998; see also Dupta and Dubey, 2003 for the effect in the context of consumption poverty). However, there is also evidence documenting larger coefficients for estimates from endogenous rather than exogenous models. For example, Rosenzweig and Wolpin (1980) noted that instrumenting endogeneity increases the coefficients compared to the exogenous model (Orbeta, 2005). For Korea, Chun and Oh (2002) found larger coefficient using instrumental variables estimates compared to OLS estimators when using households with at least one child, but smaller instrumental variables estimates when using households with at least two children. In a study of the effect on male labor supply, Lundberg and Rose (2002) also found similar results (Orbeta, 2005). Therefore, the lack of any pattern in coefficient size from the 2SLS estimator compared to the OLS estimator in the present study is not inconsistent with the available evidence.

The second point concerns the heterogeneity in coefficient signs between the rural and the urban sub-samples. The negative maternal hours of work effect of young children for the urban mother is consistent with most previous evidence although these evidences failed to run separate analysis for rural and urban mothers (see e.g. Angrist and Evans, 1998 for US; Chun and Oh, 2002 for Korea; Dupta and Dubey,
2003 for India; Cruces and Galiani, 2005 for Argentina and Mexico; Orbeta, 2005 for Philippines; Kim and Aassve, 2006 for Indonesia; Caseres-Delpiano, 2008 for 42 developing countries). This is also consistent with previous life cycle evidences. For example, Hotz and Miller (I988 and the references therein) found that children tended to have negative effects during their early ages but not during their adult ages, and that the intensity of time the mother spent tending her children markedly declined as children grow up. Similarly, Assaad and Zoari (2003) for urban Morocco found that the presence of school-age children significantly reduces the participation of women from all types of paid work (Orbeta, 2005).

The result for the rural sub-sample is in stark contrast to that of the urban sub-sample, and is inconsistent with the theoretical prediction which holds that, other factors held constant, maternal hours of work decrease with an increase in the number of young children, and increases when children become more adult. It is also inconsistent with most previous evidence. Consistent with this result, however, using data from the 2000 Ethiopian DHS and instrumenting the number of children with the husband's desire for children, Solomon and Kimmel (2009) found a positive (but insignificant) labor supply effect of children. According to Angrist and Evans (1998) in a review article, Browning (1992) also found that fertility either has no effect on maternal labor supply or it has a positive effect when endogeneity is considered.

The question now is: why is this the case? Solomon and Kimmel (2009), mentioned above, attribute the lack of statistical significance to (I) young children's possible contribution to domestic chores which allows the mother to work away from home, and (2) the high rate of unemployment and underemployment which might cause the mother's leaving her job. While the second explanation is beyond the scope of the present study because it considered wage labor alone, the first explanation is plausible.

However, Solomon and Kimmel (2009) did not run separate analyses for urban and rural mothers and did not consider lifecycle effects. We argue that the inconsistency of results for the rural households is rather due to the ruralurban difference in the employment structure and the effect of the household's lifecycle. 
First, the prevalence of household enterprises and traditional nature of farming in rural areas of poor economies means that more rural women have to work longer compared to urban women (e.g. see Arbache et al., 2010 for a research report on maternal time allocation of some African countries). The situation for Ethiopia is not different. Farm plots are fragmented, farming is done manually, and productivity is low and subsistent. Households have to invest a lot of manual labor per unit area, and as such it would be likely for households to continue working in the fields even when they have very young children at home. In such economies children may not be considered very prohibitive to the mother's hours of work given the nature of the economy and the mother's need to work for the family.

Second, work conditions are more flexible for rural economies than they are for urban economies (see e.g. Aassve and Kim, 2006). Farms are not very far from the house and the mother can use her time flexibly taking care of her child at home and working in the nearby farm plot. Even where farm plots are away from home, the mother can still manage to work. It is common, in Ethiopia for example, to see mothers doing the farming activities holding children on their backs or seating them in the shadow of a tree beside the farm with another younger child to look after the youngest child. This result has also been well confirmed by information from qualitative observation and interview with some sample households.

Third, young children in many cases contribute to the family labor by taking care of the domestic chores. The domestic labor contribution of young children is also well documented in the literature (e.g. see Aghajanian, 1979; Boserup, 1985; Caldwell and Caldwell, 1987 Cho, 2006). According to Cho (2006) children contribute to household economy by replacing the mother's activity at home. Boserup (1985) argues that in addition to their labor input, children in sub-Saharan Africa demand little child care, allowing the mother to spend her time on work. In the present study, the effect of the work contribution of members other than parents on the maternal hours of productive work is consistent with previous evidence, i.e. the existence of members engaged in non-productive work for the household increased the mother's hours of work. (see Table 6 in the Appendix). This result has also been well confirmed by qualitative observation and interviews with children and parents. In the qualitative analysis, it was found that children were able to work for the household as non-schooling children, pre-school children and school children. By contrast, the existence of members engaged in productive work decreased the mother's hours of work. Together, the results suggest the existence of work substitutability between the mother and other members of the household including children. For the urban mothers, the existence of both types of children increases the mother's hours of work, but the increase is larger and statistically significant for the existence of children engaged in non-productive work.

Equally inconsistent with theory and most available evidence as noted earlier is the more adult children's negative contribution to maternal productive work participation. In Ethiopia, it is common to see more, older mothers working only briefly or absenting themselves from farm work completely and staying home doing domestic chores compared to younger mothers. We argue that this is probably partly the result of the land tenure and administration and partly of the subsistence nature of farming coupled with poverty. Land is owned by the state since 1974 and farmers have utilization rights of the land they have held. There were periodic land redistribution schemes during the Dergue government (1974-1991). The existing government had also redistributed land in 1995/96 and has certified the farmers as a security to their land utilization right. There has not been any redistribution carried out thereafter. As a result, male children tended to continue to work on parents' land, mainly as sharecroppers, even having married and having their own family. Their marriage also increases the household's labor force, thus encouraging the mother to stay home doing the household chores. When married children might in some cases work on their own farm or engage in non-farm activities, they might have to spend some days helping on their poor parents' farms or hiring some daily labor for them. Some better-off parents were able to buy labor of their own. Evidence from the qualitative interview and observation is also revealing: children (particularly adult ones) decrease 
the mother's work outside the home thereby themselves replacing her in the farm work and allowing her to stay home doing the domestic chore.

\section{Conclusion}

This paper analyzed the effect of the number of children on maternal hours of work using Two Stage Least Squares regressions analysis. Results differ by household lifecycle and rural-urban location.

When all households are considered, coefficients are positive both for the rural and urban sub-samples and for the full sample. However, this is not the case when households are categorized by the age groups of their children. For the urban sub-sample, coefficients are negative for households with a large number of young children, and positive for those households with more adult children. The result for the urban sub-sample is roughly in line with the lifecycle hypothesis and previous evidence for other countries. By contrast, the results for the rural sub-sample are positive for households with a large number of young children, and negative for those households with more adult children. The possible explanations for this could be the need for large manual labor due to the subsistent and traditional nature of the farming system, higher flexibility between childcare and farm work, a substantial contribution of young children to domestic chores, land tenure and household poverty.

Generally our results seem to contradict traditional theory and show that Ethiopian mothers with large numbers of young children generally work longer in productive activities. While the positive contribution of children to the rural mother's hours of work participation is usually viewed positively, our results suggest that this might have been achieved at the cost of poor child care services, low school enrollment and poor quality education, and increased dependence on child domestic labor, all of which are likely to have considerable health, social, and economic implications.

\section{Notes}

'Kebele is the smallest unit in the Ethiopian administrative structure. Several kebeles make up a district.

2 The reason for stratifying households by hous- ing qualities is dictated by the need to obtain socio-economically representative data, assuming that our use of contrasting housing conditions roughly allows us to capture socioeconomically diverse households.

3 The 2SLS instrumental variable procedure is a linear procedure and requires the fulfillment of several assumptions. The data in the present study passed the Kolmogorov-Smirnov test for normality, and also passed the test for linearity and homocedasticity assumptions.

${ }^{4}$ One of the problems encountered in analyzing OLS and 2SLS estimates is that of interpreting the results. The OLS coefficient namely represents the average effect of the number of children over the entire population in the sample, whereas the 2SLS coefficient represents the average effect of the number of children for those households who have same-sex first-born siblings. Thus, the OLS results may be due to variables other than the number of children such as biases from omitted variables, and as such it is not possible to claim causal connections between the number of children and maternal hours of work. By contrast, the use of sibling sex composition provides a natural experiment whereby households with same-sex siblings are treatment groups and those with mixed sex siblings are control groups. In this case, the differences in the maternal hours of work can be attributed to the differences in the number of children due to sex composition. This allows us to plausibly infer causal connections between the number of children and maternal hours of productive work.

5 This hypothesis holds that parents can decide regarding the timing of their fertility and hours of their labor market participation, which are simultaneous and dynamic. That is, parents can simultaneously decide on the number of children they want to have and when to have them or when to work in the labor market (Cho, 2006). In this framework, therefore, parents' fertility and labor market participation decisions reflect different timing preferences. For example, couples may (I) prefer to have children early in their lifecycle delaying participation in the labor market, (2) participate in the labor market first, delaying childbearing, or (3) prefer to participate in the labor market both early and later in their lifecycle, allocating their working ages for childrearing (Cho, 2006; see also McNi- 
coll, 1984).

\section{References}

Aassve, A. and Arpino, B. 2007. "Estimation of Causal Effects of Fertility on Economic Wellbeing: Evidence from Rural Vietnam" ISER Working Paper 2007-24, University of Essex and University of Florence.

Aassve, A., Engelhardt, H., Francavilla, F., Kedir, A., Kim, J., Mealli, F., Mencarini, L., Pudney, S. and Prskawetz, A. 2005. "Poverty and Fertility in Less Developed Countries: A Comparative Analysis" in ISER, Working Paper 2005-13. Colchester: University of Essex.

Aghajanian, A. 1979. "Family economy and economic contribution of children in Iran: An overview" Journal of South Asian and Middle Eastern Studies 35, (I): 21-30.

Angrist, J. D. and Evans, W. 1998. "Children and Their Parents' Labor Supply: Evidence from Exogenous Variation in Family Size" The American Economic Review 88, (3): 450-477.

Arbache, J. S., Kolev, A. and Filipiak, E. 2010. "Why study gender disparities in Africa's labor market?" In Arbache, Jorge Saba, Kolev, Alexandre and Filipiak, Ewa (eds.) Gender Disparities in Africa's Labor Market, The World Bank (www.worldbank.org).

Baum, C. L. 2003. "Does Early Maternal Employment Harm Child Development? An Analysis of the Potential Benefits of Leave Taking" Journal of Labor Economics 2I, (2). http://www.jstor.org/stable/I 0.1086/345563.

Bianchi, S. M. 2000. "Maternal employment and time with children: Dramatic change or surprising continuity?" Demography 37, (4): 40I-4I4.

Bloom, D., Canning, D., Fink, G. and Finlay, J. 2007. "Fertility, Female Labor Force Participation, and the Demographic Dividend" In NBER Working Papers, National Bureau of Economic Research.

Boserup, E. 1985. "Economic and Demographic Interrelationships in Sub-Saharan Africa" Population and Development Review II, (3): 383-397.

Browning, M and Crossley, T. 200I. "The LifeCycle Model of Consumption and Saving" Journal of Economic Perspectives I5, (3): 3-22. (http://www.aeaweb.org/jep/archive/I503/ I5030003.pdf)
Cáceres-Delpiano, J. 2008. "Keeping the best for last: Impact of fertility on mother's employment: evidence from developing countries" Working paper 08-68, Economic series No. 32, Universidad Carlos De Madrid.

Caldwell, J. and Caldwell, P. I 987. "The Cultural Context of High Fertility in Sub Saharan Africa" Population and Development Review I3(3): 409-435.

Chatterji, P., Markowitz, S. and Brooks-Gunn, J. 2011. "Early Maternal Employment and Family Wellbeing" NBER Working paper series, No. 17212, National Bureau of Economic Research, Cambridge. (http:// www.nber.org/papers/w I 72 I 2.pdf).

Chernichovsky, D. 1978. "Personal Savings and Family Size and Composition: The Unresolved Issue," Economic and Demographic Change, IUSSP Conference, Helsinki, pp. 345-360. (Published by the World Bank, Washington) (http:// www.ozdov.com/pdfs/

personal_savings_\&_family_size_\&_composit ion.pdf)

Cho, Y. 2006. "An Analysis of Women's Fertility and Labor Supply: Implications for Family Policies." Paper presented for: International Conference on Declining Fertility in East and Southeast Asian Countries, Tokyo: 14-15 December) (http://hermes-ir.lib.hit-u.ac.jp/rs/ bitstream//0086//4/34/I/pie_dp290.pdf $\square$

Chun, H. and Oh, J. 2002. "An Instrumental Variable Estimate of the Effect of Fertility on the Labor Force Participation of Married Women" Applied Economics Letters (9): 63I634.

Cruces, G. and Galiani, S. 2007. "Fertility and Female Labor Supply in Latin America: New Causal Evidence" Labour Economics (14): 565-573.

CSA 2010. The 2007 National Population and Housing Census of Ethiopia, Addis Ababa.

CSA and ORC Macro 2000. The Ethiopian Demographic Health Survey, Addis Ababa and Calverton, Maryland

CSA and ORC Macro 2005. The Ethiopian Demographic Health Survey, Addis Ababa and Calverton, Maryland

CSA and ORC Macro 20II. Ethiopia Demographic and Health Survey 201 I (Preliminary report), Addis Ababa. 
Davies, J. 1988. "Family size, Household Production, and Life Cycle Saving" Annales D'economie Et De Statistique (9): I4I-I65.

Deaton, A. 2005. "Franco Modigliani and the Life Cycle Theory of Consumption." Paper presented for: Convegno Internazionale Franco Modgliani, Accademia Nazionale dei Lincei, Rome: February 17th-18 $8^{\text {th }}$. (http:// www. princeton.edu/ deaton/downloads/ romelecture.pdf).

Dupta, N. D. and Dubey, A. 2003. "Poverty and Fertility: An Instrumental Variables Analysis on Indian Micro Data" Working paper series 03-II, Department of Economics, Aarhus School of Business.

Gebreselassie, T. 20I I. "The Fertility Transition in Sub-Saharan Africa, 1990-2005: How Unique is Ethiopia?" In The Demographic Transition and Development in Africa: The Unique Case of Ethiopia, Teller, C. and Hailemariam, A. (eds.), Springer, London/ New York.

Hailemariam, A. Alayu, S. and Teller, C. $201 \mathrm{I}$. "The National Population Policy (NPP) of Ethiopia: Achievements, Challenges and Lessons Learned, 1993-2010." In The Demographic Transition and Development in Africa: The Unique Case of Ethiopia, Teller, C. and Hailemariam, A. (eds.), Springer, London/New York.

Hotz, V. J. and Miller, R. A. 1988. "An Empirical Analysis of Life Cycle Fertility and Female Labor Supply" Econometrica 56, (I): 19-II8. (http://links.jstor.org/ sici?sici $=0012968 / \% 2819880 / \% 2956 \% 3 A$ I $\% 3 C 91 \% 3 A A E A O L C \% 3 E 2$

IMF 2006. "The Federal Democratic Republic of Ethiopia: Poverty Reduction Strategy Paper 2003/04 Annual Progress Report" (IMF country report No. 06/27)

Jappelli, T. 2005. "The Life-Cycle Hypothesis, Fiscal Policy, and Social Security." Paper presented for: Franco Modigliani: economista tra teoria e impegno sociale, Roma: Accademia Nazionale dei Lincei, I7-I8 February. (http:// www.csef.it/papers/modigliani.pdf)

Kelley, A. and Schmidt, R. 200I. "Economic and Demographic Change: A Synthesis of Models, Findings and Perspectives." In Birdsall, Kelley, and Sinding (eds.), Population Matters. Oxford University Press, New York, pp. 67-105.
Kim, J and Aassve, A. 2006. "Fertility and its consequence on family labor supply" IZA Discussion paper series, No. 2162, Vienna Institute of Demography \& IZA Bonn and University of Essex.

Kim, J., Engelhardt, H., Prskawetz, A and Aassve, A. 2009. "Does Fertility Decrease Household Consumption? An Analysis of Poverty Dynamics and Fertility in Indonesia" Demographic Research 20, (26): 623-656.

McNicoll, J. 1984. "Consequences of Rapid Population Growth: An Overview and Assessment" Population and Development Review 10, (2): 177-233.

MoFED 2002. Ethiopia: Sustainable Development and Poverty Reduction Program, Addis Ababa.

MoFED 2006. Ethiopia: Building on Progress: A plan for Accelerated and Sustained Development to End Poverty (PASDEP) (2005/06-2009/10), Addis Ababa.

MoFED 2010. Growth and Transformation Plan (2010/I I- 2014/I5), Addis Ababa.

Morrill, M. S. 201 I. "The Effects of Maternal Employment on the Health of School-Age Children," Journal of Health Economics, 30: 240-257.

MWUD 2007. Plan for Accelerated and Sustained Development to End Poverty (2005/06-2009/10): Plan for Urban Development and Urban Good Governance, Addis Ababa.

Orbeta, A. 2005. "Children and the Labor Force Participation and Earnings of Parents in the Philippines." Discussion Paper series No. 2005-20, Philippine Institute for Development Studies.

Ringheim, K., Teller, C. and Sines, E. 2009.

Ethiopia at A Crossroads: Demography, Gender, and Development. Policy brief, Washington D. C.: A publication of Population Reference Bureau. (www.prb.com).

Schultz, T. P. 2007. "Fertility in Developing Countries" in Economic Growth Center Discussion Paper No. 953, Yale University (http://ssrn.com/abstract=985363).

Skop, E. 2006. "The Methodological Potential of Focus Groups in Population Geography" Population, Space and Place (I2): II3-124. (www.interscience.wiley.com).

Solomon, B. and Kimmel, J. 2009. "Testing the 
Inverseness of Fertility and Labor Supply: The Case of Ethiopia" IZA Discussion paper, No. 3949, Western Michigan University and IZA.

TGE 1993. The National Population Policy of Ethiopia.

UN Population Division. 2005. Population Challenges and Development Goals, Department of Economic and Social Affairs,
Report No. ST/ESA/SER.A/248, New York. UNDP 200I. UNDP Review of the Poverty Reduction Strategy Paper (PRSP), New York. UNFPA 2010. State of the World Population: Monitoring ICPD Goals

Wooldridge, J. M. 2009. Introductory Econometrics: A modern Approach. Fourth Edition. Mason: South-Western SENGAGE Learning. 
African Population Studies 27, No 2, October 2013

\section{Appendices}

\section{Appendix 1 Location of the study sites}

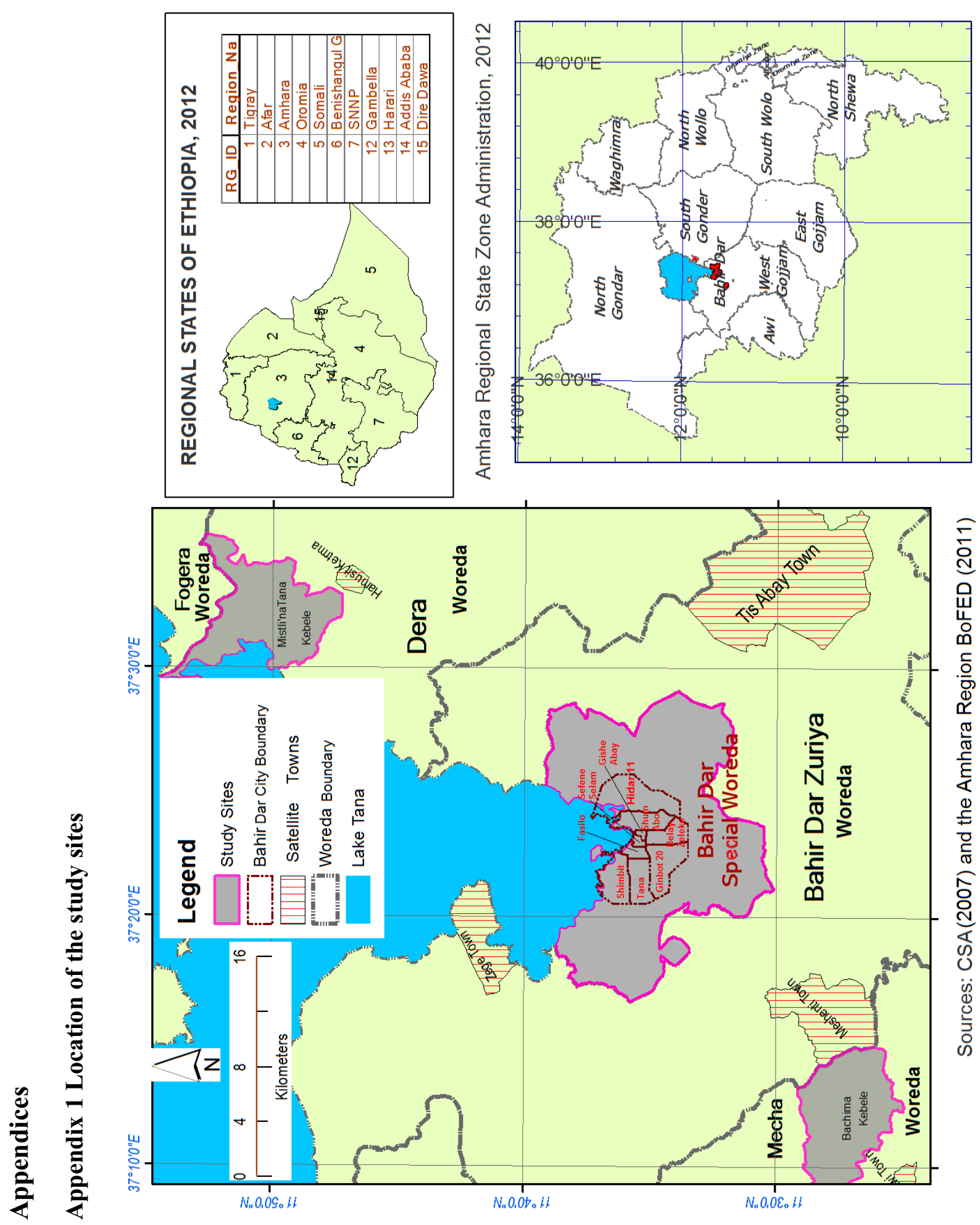




\section{Appendix 2 Control covariates and their coefficients}

\begin{tabular}{|c|c|c|c|c|c|c|c|c|c|c|c|c|c|c|c|}
\hline 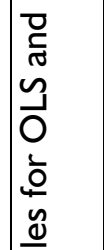 & & & $\hat{\Lambda}$ & $\overrightarrow{\widehat{\sigma}}$ & $\begin{array}{l}\stackrel{2}{2} \\
\stackrel{0}{0}\end{array}$ & $\begin{array}{l}\tilde{n} \\
\tilde{n} \\
0\end{array}$ & 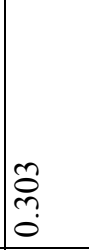 & 菅 & $\begin{array}{l}2 \\
\hat{\sigma} \\
0\end{array}$ & 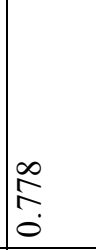 & 志 & $\stackrel{\nabla}{\widetilde{\nabla}}$ & 뭉 & $\frac{9}{2}$ & \\
\hline 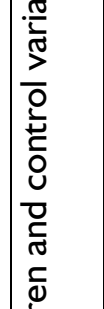 & & 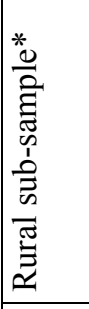 & $\dot{\ddot{\Xi}}$ & 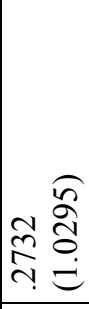 & 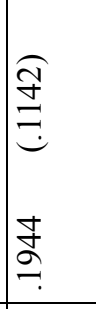 & 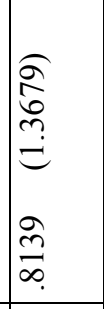 & 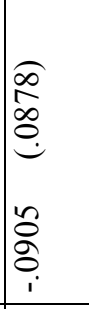 & 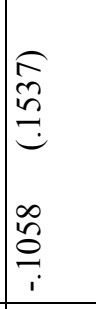 & 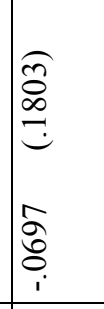 & 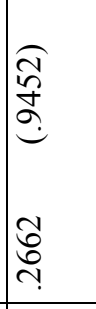 & 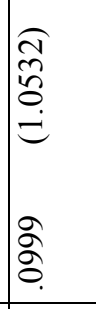 & 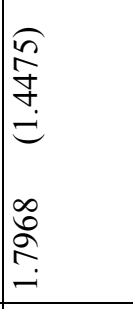 & 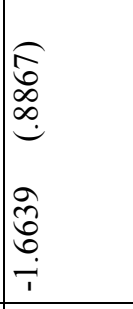 & 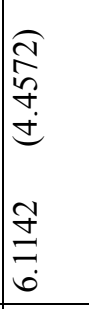 & \\
\hline 妾 & & 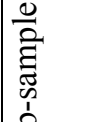 & $\hat{\Lambda}$ & 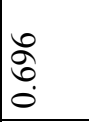 & $\mid \begin{array}{c}0 \\
\delta \\
\infty \\
0 \\
0\end{array}$ & ڤn & $\begin{array}{l}n \\
\tilde{n} \\
0\end{array}$ & $\begin{array}{l}0 \\
\stackrel{\infty}{0} \\
2 \\
0\end{array}$ & 홍 & 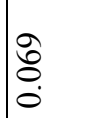 & $\stackrel{2}{\stackrel{0}{0}}$ & $\stackrel{0}{0}$ & $\frac{1}{6}$ & $\mid \begin{array}{l}\infty \\
\infty \\
0 \\
0\end{array}$ & \\
\hline 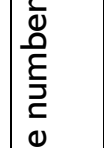 & & 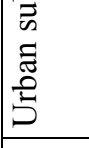 & \begin{tabular}{|l}
4 \\
$\dot{0}$ \\
$\dot{0}$
\end{tabular} & 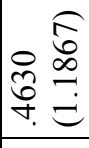 & 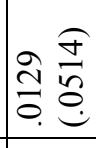 & 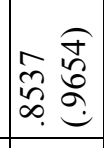 & 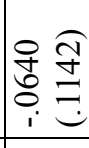 & 종 & 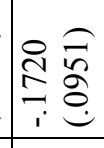 & 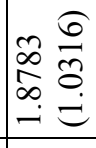 & 点 & 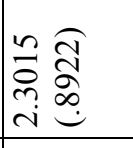 & 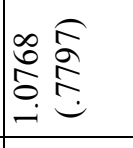 & 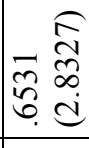 & \\
\hline ઢิ & & & $\hat{\Lambda}$ & 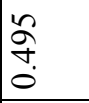 & 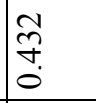 & $\frac{0}{n}$ & 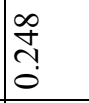 & $\begin{array}{l}\hat{0} \\
0 \\
0 \\
0\end{array}$ & $\overrightarrow{8}$ & $\underset{0}{\exists}$ & $\hat{\tilde{n}}$ & 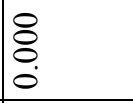 & 辛 & $\frac{2}{0}$ & \\
\hline : & $\begin{array}{l}\boldsymbol{n} \\
\overrightarrow{\tilde{N}} \\
\boldsymbol{N}\end{array}$ & 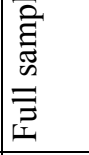 & $\begin{array}{l}4 \\
\dot{\Xi} \\
\dot{0}\end{array}$ & 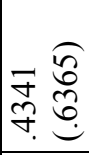 & 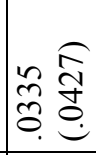 & 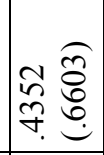 & $\begin{array}{ll}0 & \widehat{\hat{n}} \\
0 & \tilde{2} \\
0 & 0 \\
i & 0\end{array}$ & 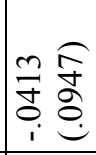 & 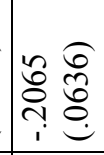 & 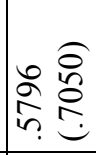 & 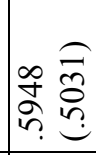 & 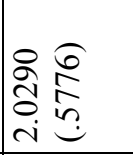 & 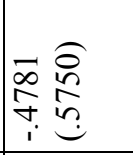 & 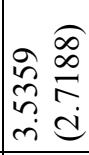 & \\
\hline$\frac{0}{2}$ & & 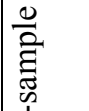 & $\overrightarrow{\hat{A}}$ & 8. & Oे. & $\begin{array}{l}0 \\
0 \\
0 \\
0 \\
0\end{array}$ & : & $\begin{array}{l}\infty \\
\tilde{n} \\
\end{array}$ & 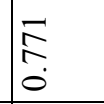 & $\begin{array}{l}0 \\
\infty \\
\infty \\
0 \\
0\end{array}$ & $\begin{array}{l}0 \\
0 \\
0 \\
0\end{array}$ & $\frac{\pi}{0}$ & $\begin{array}{l}n \\
0 \\
0 \\
0 \\
0\end{array}$ & $\stackrel{\circ}{\stackrel{7}{0}}$ & \\
\hline 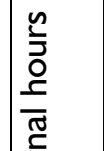 & & 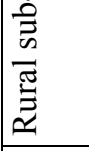 & \begin{tabular}{|l}
4 \\
$\dot{0}$ \\
$\dot{0}$ \\
$ن$
\end{tabular} & $\begin{array}{l}0 \\
0 \\
0 \\
0.0 \\
0\end{array}$ & 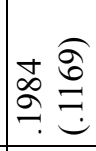 & م. & 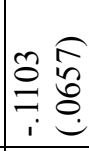 & 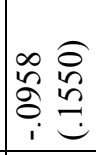 & 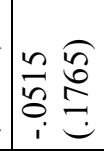 & 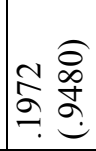 & ๙ & 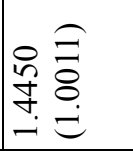 & 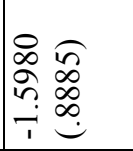 & 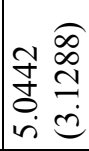 & $\begin{array}{l}\dot{\tilde{g}} \\
\underline{\tilde{J}}\end{array}$ \\
\hline 思 & & & $\overrightarrow{\hat{A}}$ & $\frac{\bar{m}}{\dot{0}}$ & $\frac{n}{a}$ & ठे & $\begin{array}{l}\circ \\
\infty \\
\infty \\
0\end{array}$ & 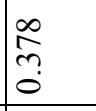 & $\begin{array}{l}\hat{2} \\
0 \\
0\end{array}$ & : & $\begin{array}{l}n \\
\tilde{o} \\
0 \\
0\end{array}$ & 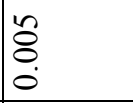 & $\frac{4}{\infty}$ & 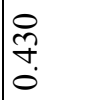 & שَّ \\
\hline . & & 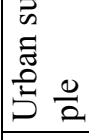 & $\begin{array}{l}\dot{\Xi} \\
\dot{8} \\
\end{array}$ & 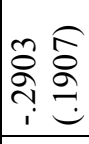 & 娄 & 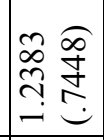 & $\begin{array}{l}0 \\
0 \\
0 \\
0 \\
0 \\
0\end{array}$ & 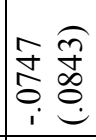 & 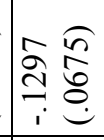 & 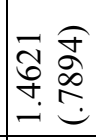 & 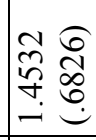 & 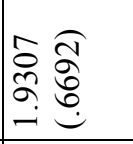 & 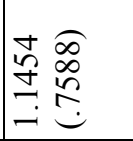 & 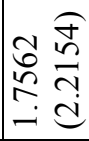 & 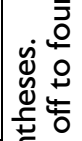 \\
\hline ల్ల & & $\frac{0}{0}$ & $\hat{\hat{n}}$ & $\begin{array}{l}1 \\
0 \\
0 \\
0\end{array}$ & $\underset{0}{\stackrel{0}{7}}$ & 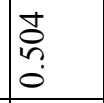 & 声 & 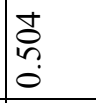 & $\overline{8}$ & $\begin{array}{c}n \\
n \\
n \\
0\end{array}$ & $\underset{\tilde{J}}{\tilde{N}}$ & ¿े. & $\begin{array}{l}\infty \\
0 \\
0 \\
0 \\
0\end{array}$ & $\underset{0}{\stackrel{\Delta}{0}}$ & 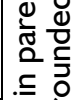 \\
\hline 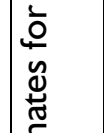 & $\begin{array}{l}n \\
0\end{array}$ & 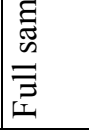 & \begin{tabular}{|l|}
4 \\
$\dot{0}$ \\
0 \\
0
\end{tabular} & 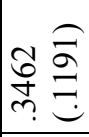 & 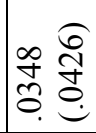 & 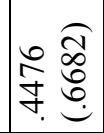 & 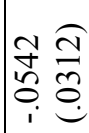 & 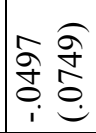 & 角 & 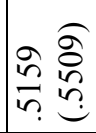 & 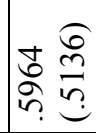 & 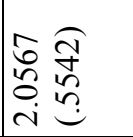 & 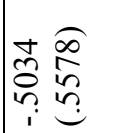 & 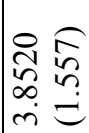 & $\mid \begin{array}{ll}0 \\
\frac{0}{0} \\
0\end{array}$ \\
\hline 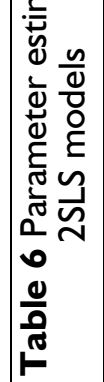 & 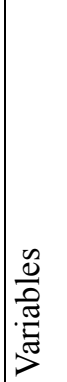 & & & 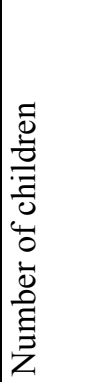 & 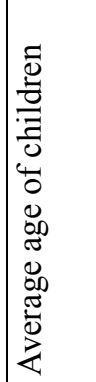 & 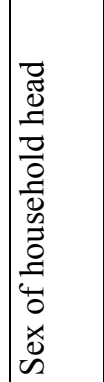 & 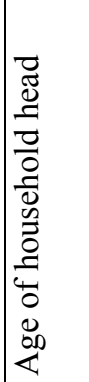 & 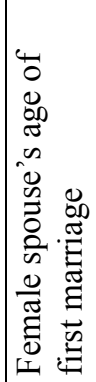 & 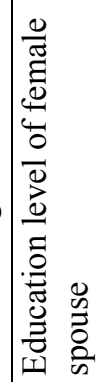 & 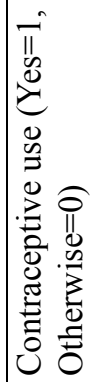 & 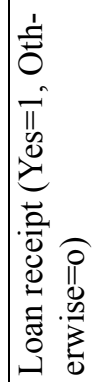 & 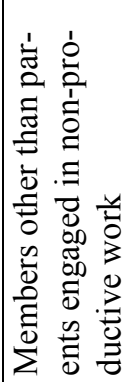 & 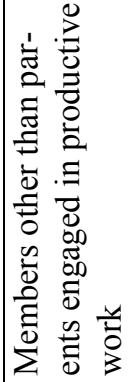 & 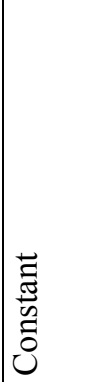 & 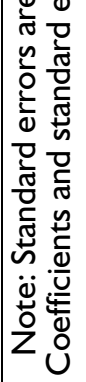 \\
\hline
\end{tabular}

